\title{
A Roller Coaster Ride: An Empirical Investigation of the Main Drivers of Wheat Price
}

\author{
Bernardina Algieri
}

\subsection{Introduction}

In recent years, food commodity prices have increased at an unusually rapid pace, and wheat prices in particular have experienced marked upsurges, only briefly interrupted by the global financial crisis. These trends can be particularly detrimental because they could amplify the incidence of poverty (IMF 2011; von Braun and Tadesse 2012; Dethier and Effenberger 2012; Benson et al. 2013), hamper economic growth in poor countries (Jacks et al. 2011), and cause worldwide unrest, such as those documented in several sub-Saharan African regions. Unrest in these regions occur because people living there spend a larger share of their income on food (about $50 \%$ ) than urban residents in other parts of the world (about $30 \%$ and $15 \%$ in middle- and high-income countries, respectively) (Portillo and Zanna 2011). Given that Africans depend on a small number of staple crops, increases in cereal prices can be particularly destructive. Spending more consumer money on food means fewer purchases of services, such as sanitation, health, and education (The Economist 2011). In addition, the Middle East and North Africa regions are the world's largest importers of cereals, particularly wheat, making them more vulnerable to higher international cereal prices. This can lead to substantial termsof-trade shocks, which affect countries' internal and external balances, with higher non-accelerating inflation rates of unemployment and balance of payments deficits.

\footnotetext{
B. Algieri $(\square)$

Department of Economics, Statistics and Finance, University of Calabria, 87036 Rende, Cosenza, Italy

Center for Development Research (ZEF), University of Bonn, 53113 Bonn, Germany e-mail: b.algieri@unical.it
} 
In this context, the present study tries to shed light on the main drivers of wheat prices by identifying the influence of the fundamental factors of supply and demand and the behavior of investors in the financial markets. In light of the steep hikes in the price of several commodities, it has become especially important to investigate the underlying factors that exert an influence on the wheat market.

Specifically, the study divides the drivers of wheat prices into market specific variables, broad macroeconomic variables, financial factors, and weather conditions. An empirical analysis was conducted based on monthly data for the period between January 1980 and January 2012 and the subperiod between January 1995 and January 2012. The quadrangulation of the drivers will allow us to better understand commodity price patterns.

The paper makes several contributions to the existing literature. It explicitly examines the case of the wheat market, merging different strands of the literature. Empirical analyses of the factors influencing wheat spot prices are quite scant (Borensztein and Reinhart 1994; Westcott and Hoffman 1999). Some studies about wheat are more descriptive in nature. For instance, Trostle (2008) and Mitchell (2008), after carrying out a graphical inspection, suggested that wheat prices increased due to a large demand for biofuels, high transportation costs, and a severe decline in global wheat supplies. Other analyses considered demand and supply factors while leaving out the role of financialization or other broad macroeconomic factors (Goodwin and Schroeder 1991; Westcott and Hoffman 1999). This study tries to extend the discussion about the wheat market by singling out specific factors behind price swings within a cointegration framework. Another novel contribution is the comparison of two long-run relationships-before and after the "financialization" of the commodity markets-to identify their similarities and differences. The last important element of this study is the ability to analyze price dynamics at a higher resolution through the use of monthly data. Most existing studies based their analysis on annual or quarterly data (Westcott and Hoffman 1999).

The rest of the chapter is organized as follows: Sect. 10.2 reviews literature about the key factors influencing commodity price; Sect. 10.3 introduces the variables of the model; Sect. 10.4 presents the VECM estimation and discusses the results; Sect. 10.5 concludes this chapter.

\subsection{Literature Review}

The roller-coaster ride experienced by commodity prices over the recent years has triggered a vivacious discussion regarding the causes of these fluctuations.

Some observers argued that the run-ups in commodity prices reflect strong changes in economic fundamentals, with price fluctuations moderated by the 
participation of nonuser speculators ${ }^{1}$ and passive investors in commodity futures markets. Others pointed to the role of broader macroeconomic factors as the main drivers of rising prices. Finally, there are also other observers who argued that commodity prices have been exuberant and divorced from market fundamentals. The first view can be dubbed the "fundamentalist" view, the second the "broad" macro-view, and the third the "financialization" view.

According to the market "fundamentalist" view (Irwin et al. 2009; Irwin and Sanders 2010; Krugman 2010a, 2011; Yellen 2011; Dwyer et al. 2011, 2012), the price of any goods or assets should be driven by demand and supply in the absence of "irrational exuberance." In this context, any shocks to demand and supply which lead to rising global demand and disruption of global supply cause relevant price swings. Negative shocks to agricultural commodity supplies, which cause commodity prices to surge, are mainly the result of adverse weather conditions or collapses in the stock-to-use ratios. In other words, extreme weather conditions are likely to damage existing cropping areas, resulting in greater yield variability and negatively affecting price changes. Additionally, when stock-to-use ratios are low, the market is less able to cope with a significant decline in supply or a drastic increase in demands and thus drives prices significantly upwards (Williams and Wright 1991; Gilbert and Morgan 2011). Preexisting stocks are thus a fundamental source of stability in commodity markets. According to a report by the FAO (2009) about the prerecession spike in food commodity prices, stock levels have been decreasing by an average of $3.4 \%$ per year since the mid-1990s, and the highest prices were registered during a period in which the stock-to-use ratios were at historical lows. Low food stocks and low crop stocks exacerbate the effects of weather disruptions on prices. For instance, wheat prices increased by $47 \%$ in 2010 , which was largely attributable to droughts in Russia and China and to floods in Canada and Australia.

With respect to demand, the process of income catch-up (convergence) between developing and advanced countries has triggered a growth in demand for commodities and hence drove up commodity prices. More than $90 \%$ of the augmentation in demand for agricultural commodities in recent years has originated from developing countries, mainly from India and China (Heap 2005; Coxhead and Jayasuriya 2010; Fawley and Juvenal 2011; Cevik and Sedik 2011). In Krugman's words (2010b), rising commodity prices are a sign that "we are living in a finite world, in which the rapid growth of emerging economies is placing pressure on limited supplies of raw materials, pushing up their prices." However, it should be noted that in real terms, the price of food commodities has increased by $75 \%$ between 2003 and 2008 (Erten and Ocampo 2013). This pattern is a reversal of the strong downward trends experienced since the 1980s, but it is still too early to assess if the reversal implies a long-term change (shift) in the direction of the trend, a pronounced short-run food

\footnotetext{
${ }^{1}$ A rational expectations model predicts that the existence of a futures market would reduce the fluctuation of spot prices for reasonable value of input parameters.
} 
commodity price spike around the long-run trend, or a commodity price super-cycle (Rogers 2004; Heap 2005; Jacks 2013).

According to the "broad" macro-view, other macroeconomic determinantssuch as exchange rates, monetary policies, inflation, energy price, global economic activity, and the "thinness" of markets-could have affected price levels and their fluctuations via demand or supply channels. For instance, exchange rates can influence commodity prices through several conduits, such as international purchasing power and the effects on margins for producers with non-US dollar costs (Mussa 1986; Gilbert 1989; Borensztein and Reinhart 1994; Roache 2010; Manera et al. 2013). This means that dollar depreciation increases costs to US producers and consumers in areas where the US dollar is the currency of trade. A change in the US dollar exchange rate thus affects prices measured in US dollar terms, but its effect will be nullified if prices are measured in terms of a weighted basket of currencies. Monetary policies, including interest rate maneuvers, can affect a number of demand and supply channels as well (Orden and Fackler 1989; Frankel 2008; Calvo 2008; Bakucs et al. 2009), leading to greater movements in real commodity prices when changes in real interest rates become frequent. This occurs particularly when interest rates are low and when there is an incentive to hoard physical commodities as an investment vehicle, causing prices to go up. Inflation is a common driver of prices of different commodities. Oil prices have also been mentioned as an additional factor in causing food price shocks via demand channels (Mercer-Blackman et al. 2007; Thompson et al. 2009). This is because a surge in oil prices leads to an increase in demand for grains as biofuels, and this subsequently causes food commodity prices to rise. $^{2}$

Market "thinness," which is defined as the combined share of imports and exports relative to the size of global consumption or production, also significantly affects commodity price movements. In thinner markets, in which domestic prices do not closely follow international market movements, world market prices have to vary more to accommodate an external shock to traded quantities (OECD 2008).

Some observers doubt that fundamental shocks could be used as a reason to fully justify the price run-ups. Instead, they point to the "financialization" of commodity markets and speculation as the main causes of the drifts and fluctuations of commodity prices (Masters 2008; Stewart 2008; Hamilton 2009; Gilbert and Morgan 2011; Tang and Xiong 2012). "Financialization" refers to the large flow of capital into commodity markets, more specifically into long-only commodity index funds (Acworth 2005; Domanski and Heath 2007; Miffre 2011; Miffre and Brooks 2013). Speculation involves buying, holding, and selling of stocks, bonds,

\footnotetext{
${ }^{2}$ To reduce oil dependence as the main source of energy, several countries, including the USA, have adopted new energy policies to promote the use of biofuel. The 2005 US energy bill mandated that 7.5 billion gallons of ethanol be used by 2012. The 2007 energy bill further raised the mandate to 36 billion by 2022 . The mix of increasing ethanol subsidies and high oil prices determined a rapid growth of the ethanol industry, which consumes about one-third of the US maize production. The rise of the ethanol industry might have led prices of maize, and other close substitutes such as soybeans and wheat, to co-move with oil prices (Roberts and Schlenker 2010; EPA 2012).
} 
commodities, or any valuable financial instruments to profit from fluctuations in their price. This is in contrast to market participants buying these assets for use, dividends, interest income, or hedging purposes (Robles et al. 2009). Speculation thus may take the form of speculative stockholding, speculative purchase and the sales of commodity futures, or other derivative contracts.

Similarly, a report by the US Senate's Permanent Subcommittee on Investigations (USS/PSI 2009, p. 2) argued that commodity traders and futures contracts were disruptive forces, pushing prices away from fundamentals, and inducing excessive price movements.

In this context, some believe that a speculative bubble is forming in commodities as a consequence of the highly accommodative stance of the US monetary policy. Some of the accommodative policies include the maintenance of the target federal funds rate at exceptionally low levels (Hamilton 2009) and extremely high flows of investment funds into commodity futures. Loose monetary policies influence commodity prices by reducing the cost of holding inventories or by encouraging "carry trades" and other forms of speculative behavior (Frankel 2013). However, the "fundamentalist" view points to the fact that stocks of agricultural products have generally been falling between 2006 and 2008 as evidence that undermines the hypothesis that speculators contributed to the spike in prices.

The financialization hypothesis suggests that prior to the recession, the surge in commodity prices was accompanied by a large inflow of funds. According to Barclays, index fund investment in commodities increased from $\$ 90$ billion in 2006 to about $\$ 200$ billion by the end of 2007; in July 2011, the amount of investment reached a historical peak of $\$ 431$ billion. In this context, the large-scale speculative buying of index funds during the boom caused commodity future prices to far exceed fundamental values, thus creating a "bubble." However, people who hold the fundamentalist view again argued against the "speculation theory," pointing out that commodities without futures markets have experienced approximately as much fluctuations as commodities with a derivative market.

\subsection{Variables and Data}

In order to empirically examine the causes of price fluctuation, wheat spot prices were considered. The sample consists of monthly wheat spot prices for the period 1980-2012, and a subperiod is defined as 1995-2012. The subsample starts in 1995 due to the unavailability of some financial data before that year. To identify the key drivers, the different strands of the existing literature were merged, and the driving forces behind wheat prices were divided into four dimensions: market specific variables, broad macroeconomic variables, speculative components, and weather conditions. A detailed description of the data can be found in the Annex.

The focus is on the spot market rather than the futures market for two main reasons. First, it is important to understand the interconnections between the two markets and assess how trading activities in the futures markets affect the patterns of spot prices for their economic and welfare consequences. Second, the existing 
analyses are mainly focused on commodity futures markets and less on the cash markets.

Wheat spot prices were taken from the IMF International Financial Statistics, via Datastream. The prices are expressed in US dollars, averaged from daily quotations, and have been deflated by the US consumer price index to obtain their real values. The prices were then converted into an index $(2000=100)$.

Market Specific Variables include inventory-to-consumption and the "thinness" of markets.

\section{Inventory-to-Consumption}

\section{$(-)$}

Inventory stock levels have a crucial role in commodity pricing (Williams and Wright 1991; Pindyck 2001; Krugman 2011). As in manufacturing industries, inventories are used to reduce costs of adjusting production over time in response to fluctuations in demand and to shrink marketing costs by facilitating timely deliveries and preventing stock-outs. Producers can reduce their costs over time by selling out of inventories during high-demand periods and replenishing inventories during lowdemand periods. Since inventories can be used to ease production and marketing costs despite fluctuating demand conditions, they lower the degree of short-run market price fluctuations. Therefore, price levels and their fluctuations are expected to increase when the level of inventories is lower.

Because inventory holdings can change, production at any period does not need to be equal to consumption. As a result, the market-clearing price is determined not only by current production and consumption but also by changes in inventory holdings.

Aggregate world stocks at the end of a year were expressed as a proportion of the aggregate world consumption from the previous year. This ratio is also referred to as the stock-to-use ratio (Fig. 10.1). The inventory data are the predicted end-

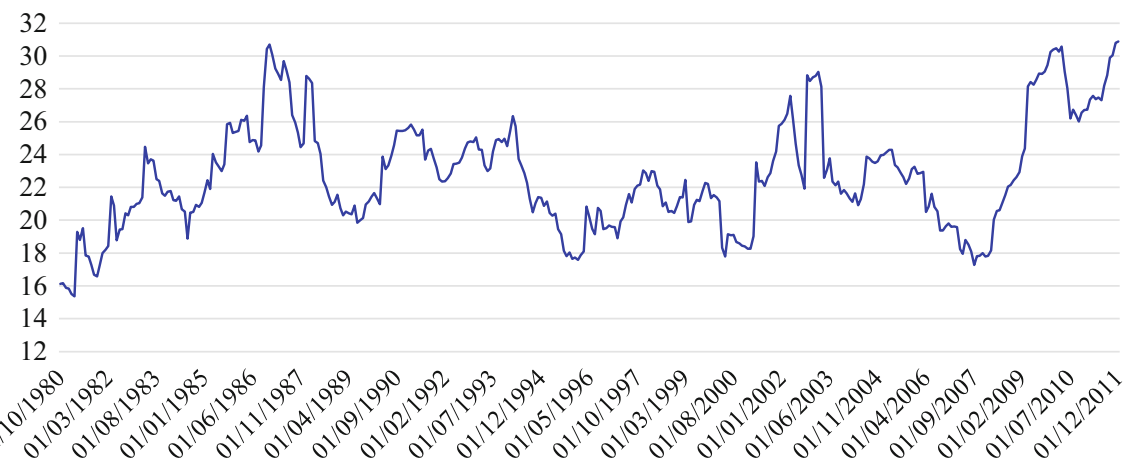

Fig. 10.1 End stock-to-use ratio (in \%) 
of-season global wheat inventories as published in the monthly USDA reports. Therefore, the inventories are the projected quantities of grain reserves carried over from the ongoing marketing year to the new marketing year. The definition of a marketing year is based on the aggregate of local marketing years. The largest trader of wheat in the international market is the USA, where the marketing season starts at the beginning of June and ends at the end of May. The consumption data are the projected season's consumption levels. The data was obtained from the United States Department of Agriculture (USDA).

\section{International Thinness of Markets}

\section{$(+) /(-)$}

The "thinness" of a market refers to the share of the imports and exports of a specific commodity relative to the size of global consumption or production (OECD 2008). This ratio describes the extent to which agricultural products are internationally traded. ${ }^{3}$ The thinness of the wheat market can be expressed as follows:

$$
\mathrm{TH} \equiv\left(\frac{\mathrm{EX}_{w}+\mathrm{IM}_{w}}{\mathrm{Cons}_{w}}\right)
$$

A low ratio means that the market is "thin," while a high ratio implies "fatness" of the market. Hence, a thin market is characterized by low trading volume.

The thinness of a market could exert two opposite effects on prices. Higher trading volume may lead to higher demand for commodities; this could result in a price run-up. Conversely, trade could help smooth production and consumption across space by moving goods from regions with surplus to those with deficit, thus mitigating the effects of price movements. In this context, more trade implies more stability and price drops, while a lack of trade implies high movements and price increases (Jacks et al. 2011). Increased trade integration would thus facilitate the stabilization of food prices and the reduction of prices for consumers (The World Bank 2012).

In regards to volatility, thin markets, characterized by low trading volumes, tend to show high fluctuations (illiquid), while fat markets display high trading volumes and high liquidity. It is often argued that agricultural markets are "thin"; the ratio of trade flows to global production/consumption is considered low as a consequence of protectionist measures or because a commodity is mostly consumed in their country of production, as in the case of rice (Timmer 2009). This causes price swings that are larger than those expected in more liquid or deeper markets. In the case of wheat,

\footnotetext{
${ }^{3}$ The construction of this measure includes exports and imports to be conceptually parallel to the degree of openness of an economy. As imports equal exports at a global level, the thinness index could also be represented by either exports or imports.
} 
a change in thinness can be considered as a more direct proxy for changes in trade policy since wheat is consumed independently from where it is produced, and the market dimension is more linked to the existence of restrictive or expansive trade policies.

When markets are thinner and prices in domestic markets do not follow those in international trade because of insulating policies or market imperfections, world market prices must change to better accommodate an external shock to the traded quantities, if all else is equal. Trade thus is an important buffer against localized fluctuations originating from the domestic market and could also be useful for leveling out local supply shocks around the globe.

Broad macroeconomic variables include global economic activity, interest rates, real exchange rates, oil price, and inflation.

\section{Global Economic Activity \\ $(+)$}

The monthly global industrial production index was considered when measuring the global economic activity. The index was chosen because real world GDP data is not available on a monthly basis but only at quarterly frequency. Initially, industrial production data for advanced and emerging economies were considered separately when analyzing the impact of aggregate demand growth; however, these data are available only at annual frequency, and in any case, world figures have the advantage of including emerging countries such as China and India. This is in line with the study by Frankel and Rose (2009).

\section{Interest Rate and Yield Curve}

$(-) \&(+) /(-)$

Real interest rates can influence commodity prices in several ways, as explained by Frankel $(2006,2012,2013)$. For instance, the prices of storable commodities rise as interest rates fall because, by decreasing the cost of carrying inventories, lower rates stimulate inventory demand for commodities. On the other hand, a rise in interest rates reduces inventory demand since it increases the cost of carrying inventories. This, in turn, lessens commodity prices.

Another mechanism by which real interest rates affect commodity prices relates to financial speculation in commodity markets. Commodities can be thought of as financial assets; thus when real interest rates are very low, investors are more prone to take open positions in the financial market for commodities, thereby pushing commodity prices up. Conversely, an increase in interest rates encourages speculators to shift from spot commodity contracts to Treasury bills, and this curbs commodity prices. Following this line of thought, Calvo (2008) put forward that increases in commodity prices mostly stem from the combination of low central bank interest rates, the growth of sovereign wealth funds, and the consequent lower demand for liquid assets. 
In order to account for the effects of monetary policies, the US money market rate (federal funds) deflated by the consumer price was considered. The interest rate is thus expressed in real values.

In addition, to gain insights into the expected future path of the short-term interest rates, the US interest rate spread has been included, constructed as the difference between the 10-year Treasury bonds and the federal funds. This spread, or difference between long and short rates, is often called the yield curve. It can be considered as an indicator of the stance of monetary policy and general financial conditions because it rises (falls) when short rates are relatively low (high). A negative yield curve (i.e., short rates are higher than long rates) is historically a particularly strong indicator of recession. In short, it is a leading indicator which signals changes in the direction of aggregate economic activity.

The expected relationship between yield spread and commodity prices is uncertain. If risk premiums on Treasury Bond represent a reward to investors for their exposure to economy-wide macroeconomic risks, then we should expect a strong positive linkage between variation in commodity spot prices and measures of risk in Treasury bond markets. This indicates that higher yield spreads, which signal a declining risk tolerance in the Treasury bond market, mean higher commodity prices, which indicate an increasing risk tolerance in the commodity markets. This pattern is consistent with the thesis that asset classes are being treated as substitutes in diversified portfolios.

If risk aversion is instead expressed in a similar way across the Treasury and commodity markets during the period, then rising Treasury yields are correlated with lower commodity prices. This pattern is consistent with the thesis that asset classes are being treated as complements in diversified portfolios.

\section{Oil Spot Price}

\section{$(+)$}

The oil price is a critical factor contributing to the increase in production costs of agricultural commodities and food (costs of processing, transportation, and distribution) and consequently to the increase in their market prices. Additionally, an increase in oil price provides an incentive to produce biofuels, thus exerting a further upward pressure on food commodity prices. Therefore, wheat prices and oil prices are expected to be positively related.

Crude oil prices were obtained from Cushing, Oklahoma West Texas Intermediate (WTI) Spot Price FOB (Dollars per Barrel) via Datastream. To obtain the real values, the average petroleum spot price was deflated using the US CPI.

\section{Real Effective Exchange Rate}

$(+) /(-)$

Many agricultural commodities (as with oil) are traded in the US dollar; this implies that the effective exchange rate of the US dollar affects commodity prices as perceived by countries other than the USA. Therefore, a change in the dollar exchange rate can change the demand for and supply of agricultural commodities 
and consequently their prices. A real exchange rate appreciation (depreciation) can be positively or negatively related to prices.

On the one hand, dollar depreciation tends to reduce the commodity prices in domestic currencies for countries and regions with floating exchange rates, such as the euro area, Japan, the Philippines, and South Korea. This leads to an increase in the demand for commodities in these areas. Therefore, dollar depreciation has a positive impact on the demand for commodities and should contribute to rising commodity prices. Conversely, dollar appreciation makes exports less competitive and decreases the demand for commodities, causing dollar-denominated international commodity prices to diminish. This has a neutral effect for countries that peg their currency to the US dollar, like Oman, Saudi Arabia, Eritrea, and Hong Kong.

On the other hand, if uncertainty increases, both the demand for the dollar and commodities will increase, causing commodity prices to rise.

\section{Inflation}

$(+)$

Since commodities are considered to have the ability to store value, demand for commodities, for use as financial assets or as stocks, increases with inflation. Inflation tends to affect commodity prices through the portfolio choices of financial investors; this occurs because holding commodities can hedge investment portfolios against inflation risks (Roache 2010). The inflation rate is computed using changes in the US consumer price index.

To account for Financial Variables, a measure of financialization and speculation in the wheat market has been included.

\section{Financialization and Speculation}

\section{$(+) /(-)$}

Commodity markets have seen a progressive financialization over time. This is evident in the evolution of the level of open interest. Open interest describes the total number of long (purchased contracts outstanding) or short (sold contracts outstanding) futures contracts for a given commodity in a delivery month or market that has been entered into but not yet (1) liquidated by an offsetting transaction or (2) fulfilled by the delivery of the commodity. ${ }^{4}$ Open interest is hence a widely used measure of the size of a commodity futures market. Specifically, Fig. 10.2 shows the open interest disaggregated by the type of traders and the nature of contracts in the wheat market; that is, it considers the long and short open interests for commercial traders, noncommercial traders, and non-reportables.

Commercial traders, also known as hedgers, hold positions in the underlying commodity and attempt to offset their risk exposure using future transactions. Noncommercial traders, also called speculators, only hold positions in futures

\footnotetext{
${ }^{4}$ In analytical terms, the market's total open interest is the sum of reporting and non-reporting positions: TOT OI $=[\mathrm{NCL}+\mathrm{NCS}+2 \times \mathrm{NCSP}]+[\mathrm{CL}+\mathrm{CS}]+[\mathrm{NRL}+\mathrm{NRS}]$, where noncommercial open interest (NC) is distinguished in long (NCL), short (NCS), and spreading (NCSP), while for commercials (C) and non-reportables (NR) open interest is divided in long and short.
} 

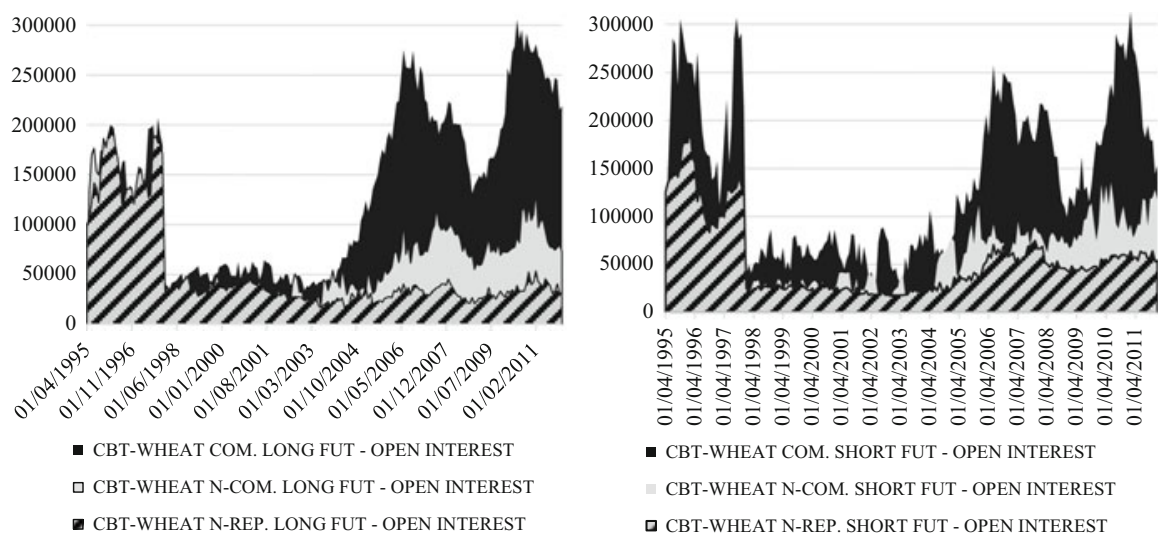

Fig. 10.2 Role of commercials, noncommercials, and non-reportables in wheat market (Chicago Board of Trade). Source: Own Elaboration on Datastream

contracts and are not involved in the physical commodity trade. Commercial and noncommercial traders are defined as reportable traders because they hold positions in futures and options at or above specific reporting levels set by the US Commodity Futures Trading Commission (CFTC). Non-reportables refer to small traders who do not meet the reporting thresholds set by the CFTC. Traders could take either long (buy) or short (sell) positions in commodity futures markets, depending on whether commodity prices are expected to appreciate or depreciate.

It is worth noting that although wheat futures can also be traded on the Kansas City Board of Trade (KCBT), and the Minneapolis Grain Exchange (MGEX), figures in this chapter come from the Chicago Board of Trade (CBOT) because it is the world's oldest futures and options exchange and the largest commodity exchange in the world. Founded in 1848, it accounts for about half of the turnover in futures contracts in the USA and the bulk of the world's grain futures trading.

As shown in Fig. 10.2, open interest recorded significant gains from 2003 onward, only registering a drop during the financial crisis but surged again soon afterwards. The fact that the long and short positions of all types of investors in the wheat market have increased over time suggests a rise in the financialization of commodity futures markets.

In a well-functioning futures market, hedgers, who want to lower their exposure to price risks, will have to find a counterparty. In the absence of any speculative activity, long hedgers have to find short hedgers with an equal and opposite position. Since long and short hedgers do not always trade simultaneously or in the same contract amount, there is unmet hedging demand, which speculators can satisfy. Speculators thus reduce searching costs by taking the opposite positions when 
long and short hedgers do not perfectly match each other's demand (Büyükşahin and Harris 2011). This follows Friedman's (1953) argument: speculators stabilize prices by buying low and selling high so as to bring prices closer to fundamentals. However, it turns out that speculative activities often exceed the level required to offset any unbalanced hedging, thus destabilizing markets. According to De Long et al. (1990), rational speculators set price trend and lead shortterm prices away from fundamentals by anticipating the buy/sell orders of trend followers.

In short, the financialization of commodity markets has brought about an increase in speculative activities, which could have positive or negative effects on commodity markets, and consequently on prices.

Since the share of net long positions of noncommercial traders is frequently used as a variable to capture the activity of financial investors in commodity markets (IMF 2006; Micu 2005; Domanski and Heath 2007), an excessive-speculation index has been constructed following Working (1953). This metrics is a good measure of speculative activities in futures markets since it assesses the relative importance of speculative positions with respect to hedging positions. And as Working suggested, the level of speculation is meaningful only when compared with the level of hedging in the market. The Working index has been used also by Sanders et al. (2010) and Büyükşahin and Harris (2011) to examine the adequacy or excessiveness of speculative participation in the commodity futures markets. The excessive-speculation index is expressed as:

$$
\mathrm{ESPI} \equiv\left\{\begin{array}{l}
{\left[1+\frac{\mathrm{NC} \text { OI Short }}{(\mathrm{C} \text { OI Short }+ \text { C OI Long })}\right] \times 100 \text { if } C \text { OI Short } \geq C \text { OI Long }} \\
{\left[1+\frac{\mathrm{NC} \text { OI Long }}{(\mathrm{C} \text { OI Short+C OI Long) }}\right] \times 100 \text { if } C \text { OI Short }<\text { C OI Long }}
\end{array}\right.
$$

where NC OI Short=open futures position of short speculators, NC OI Long $=$ open futures position of long speculators, C OI Short = open futures position of short hedgers, and C OI Long = open futures position of long hedgers. In other words, the nominator denotes the short and long speculative positions. The denominator is the total amount of futures open interest resulting from hedging activity.

Figure 10.3 shows the excessive-speculation index in the wheat market and its descriptive statistics. 


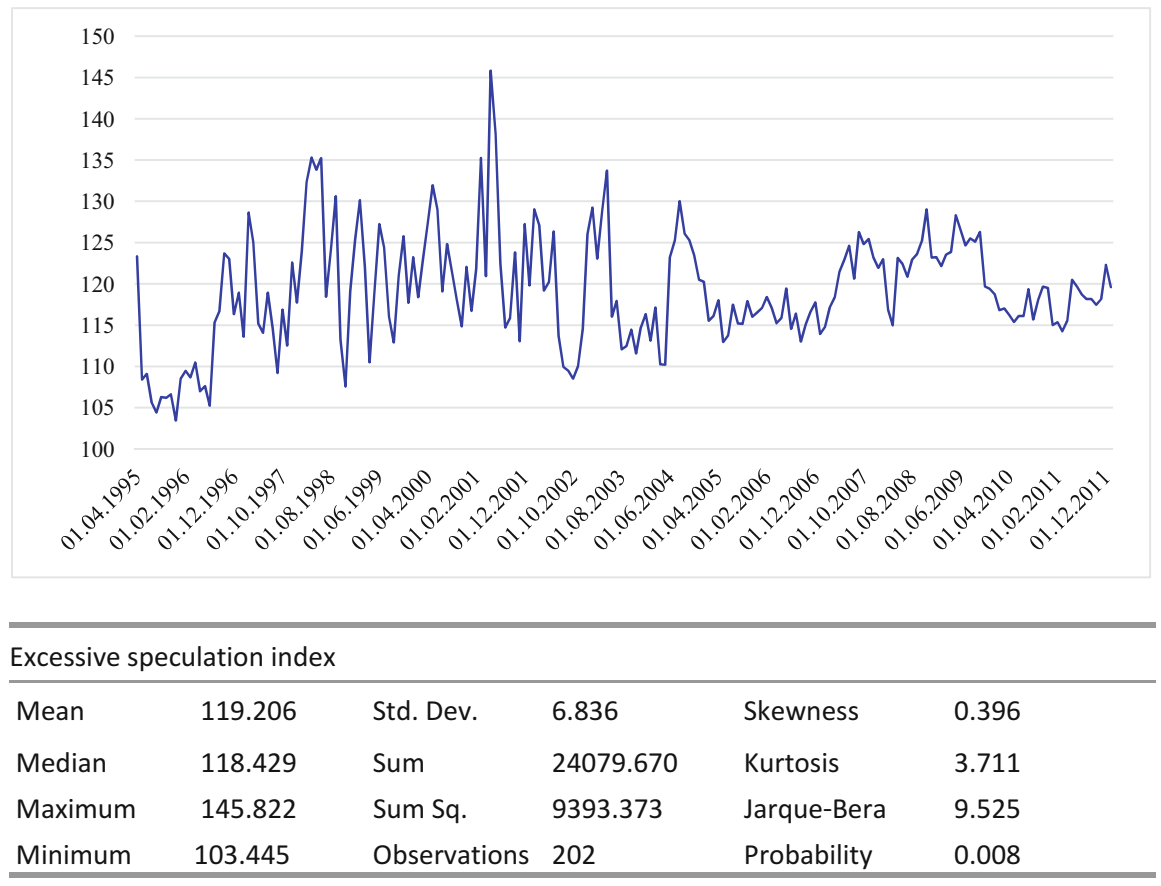

Fig. 10.3 Excessive-speculation index. Wheat CBOT

Finally, the model controls for Global weather conditions. To account for weather conditions, the following two indicators have been considered:

- The sea surface temperature anomalies (SST) for the El Niño region 3.4 (a central region of the Pacific Ocean). This index measures the deviations between the sea surface temperatures in the El Niño region 3.4 and its historical average, and it is calculated by the National Climatic Data Center US Department of Commerce and the NOAA Satellite and Information Service using the extended reconstructed sea surface temperature.

- The Southern Oscillation Index anomalies (SOI), which measures the fluctuations in air pressure occurring between the western and eastern tropical Pacific during El Niño and La Niña episodes (i.e., the state of the Southern Oscillation). It is a standardized index based on the observed sea-level pressure differences between Tahiti, French Polynesia, and Darwin (Australia). In general, a negative phase of the SOI represents below-normal air pressure at Tahiti and abovenormal air pressure at Darwin. SOI data are taken from the National Oceanic and Atmospheric Administration National Climatic Data Center. 


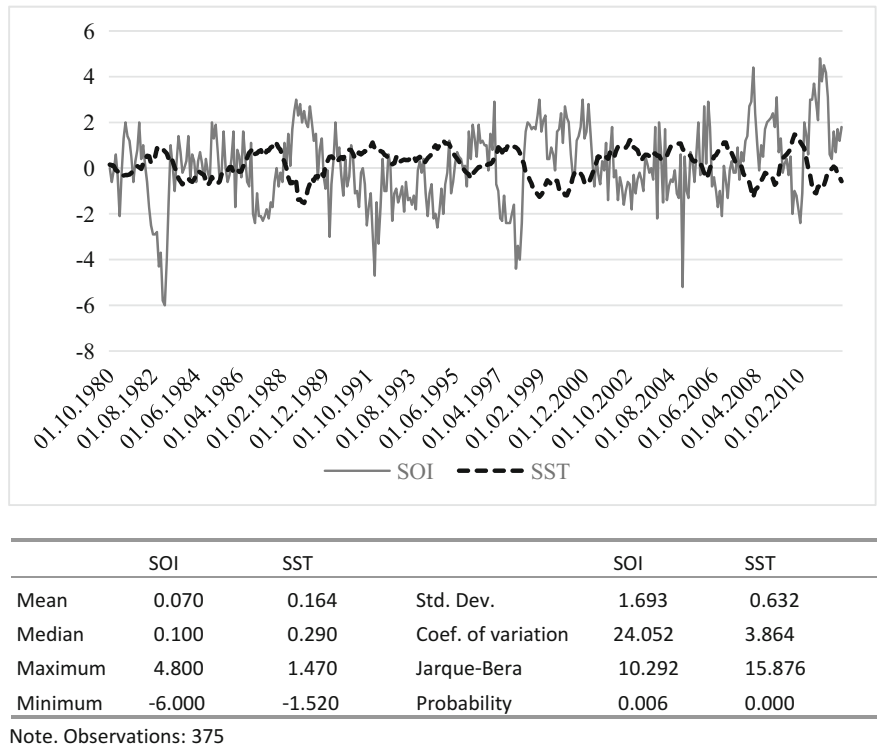

Fig. 10.4 Weather proxies

Although the events described by these indices arise in the Pacific Ocean, they have strong effects on the world's weather and an important influence on the global production and price of primary non-oil commodities (Brunner 2002). Monitoring both the SOI and the SST allows for a better understanding of global climatic fluctuations, enabling us to clearly distinguish between the atmosphere's and the ocean's influence on yield, and thus prices. In addition, evaluating both variables together significantly improves the accuracy of weather forecast when compared to using them separately (Russell et al. 2010).

The dynamics of the SST index and the SOI are reported in Fig. 10.4. With regard to the SST index, positive anomalies (index values above zero) are related to abnormally warm ocean waters across the eastern tropical Pacific typical of an El Niño event, and negative anomalies are related to a cool phase typical of a La Niña episode. Conversely, prolonged periods of positive SOI values (values above zero) coincide with La Niña events during which water becomes cooler than normal; the 
opposite is true for prolonged periods of negative SOI values. SOI values below zero mirror El Niño episodes, during which water becomes warmer than normal. La Niña events are associated with increased instances of drought throughout the mid-latitudes, where much of the global wheat and other grains (such as corn and soybeans) are produced, thus decreasing their global yield (Hurtado and Berri 1998) and driving up prices. For this reason, La Niña episodes have historically been associated with global food crises. El Niño is associated with an increased likelihood of droughts in tropical land areas, which mainly affects crops such as sugar and palm oil.

It is worthwhile to note that the SST index and the SOI tend to have opposite signs and that the SOI has a higher variability than the SST index as computed by the coefficient of variation shown below.

\subsection{Empirical Evidence}

\subsubsection{Preliminary Unit Root Test}

Prior to testing for cointegration, the time series examined in Sect. 10.3 were transformed into logarithms, and their properties were carefully investigated. The transformation of the time series into logarithm is of advantage as the coefficients can be interpreted as elasticities. Inspecting the data graphically (Fig. 10.5) reveals that most of the series resemble a random walk, with some "trending" upward and others downward, and with fluctuations. Therefore, the Augmented Dickey-Fuller (ADF) (1981) and the Philips Perron (P-P) (1988) tests have been conducted for each variable to formally test for the presence of unit roots. The critical values for the rejection of the null hypothesis of a unit root are those computed according to the MacKinnon criterion (1991). The lag length for the ADF test is based on the Schwarz information criterion (SIC). The lag structure for the P-P is selected using the Bartlett Kernel with automatic Newey-West bandwidth. The two tests have been carried out with a constant and a linear trend (Table 10.1).

The ADF and P-P tests show that all the independent and dependent variables are integrated of order one I(1), i.e., the series become stationary after being differentiated for the first time. This occurs because the computed values do not exceed the Mac Kinnon critical values. The only exceptions are for the US Fed spread and the SST index, which produced different results according to the two tests. ${ }^{5}$ However, it is acceptable to consider the series integrated of order

\footnotetext{
${ }^{5}$ Although Engle and Granger's (1987) original definition of cointegration refers to variables that are integrated of the same order, Enders (2009) argued that: "It is possible to find equilibrium relationships among groups of variables that are integrated of different orders." Asteriou and Hall (2007) also explained that in cases where a mix of $\mathrm{I}(0)$ and $\mathrm{I}(1)$ variables are present in the model, cointegrating relationships might exist. Similarly, Lütkepohl and Krätzig (2004) explain: "Occasionally it is convenient to consider systems with both $\mathrm{I}(1)$ and $\mathrm{I}(0)$ variables. Thereby the concept of cointegration is extended by calling any linear combination that is $\mathrm{I}(0)$ a cointegration
} 


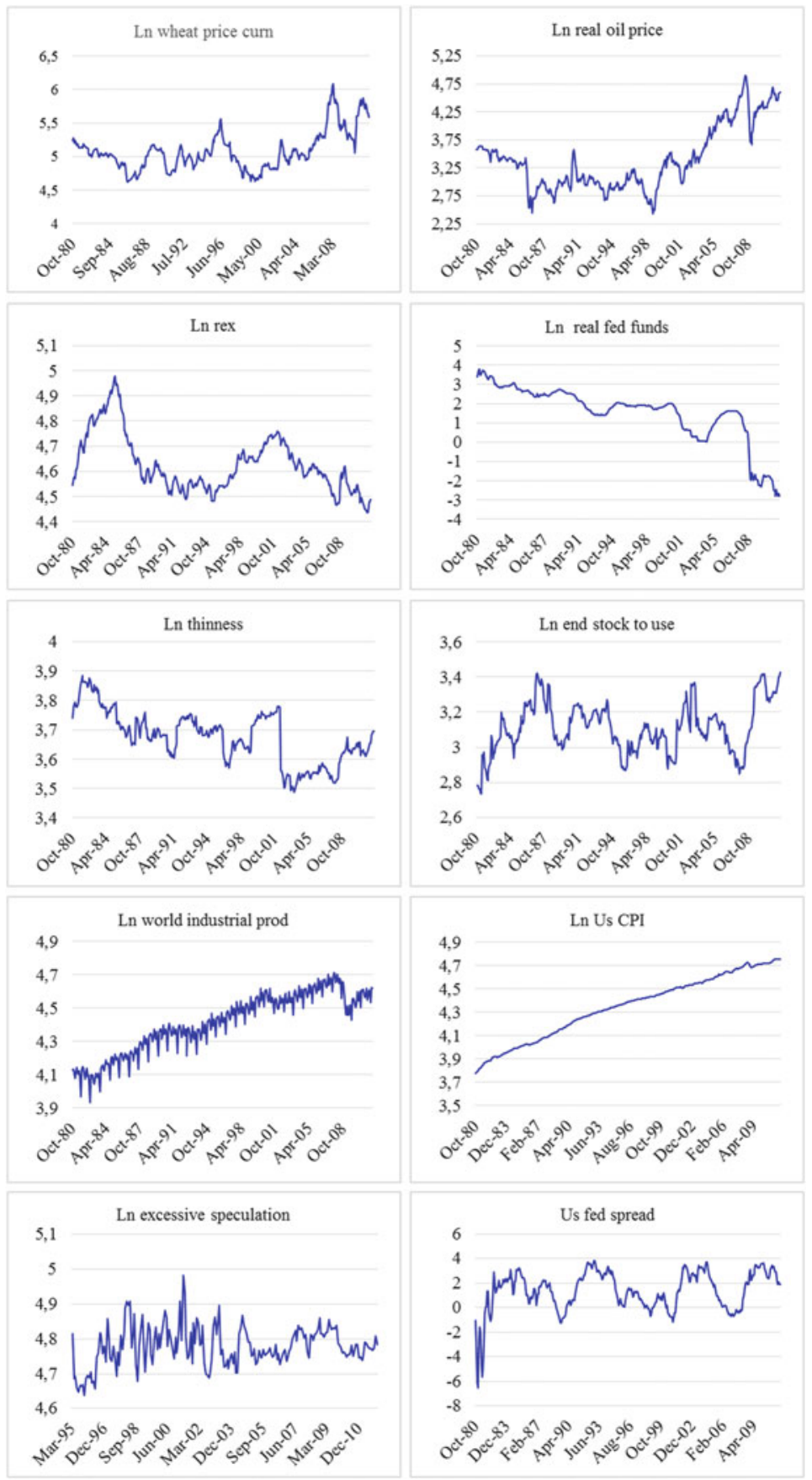

Fig. 10.5 Variables developments 
Table 10.1 Unit root tests

\begin{tabular}{l|l|l|l|l|l|l|l|l}
\hline & \multicolumn{2}{|l|}{ ADF level } & \multicolumn{2}{l|}{ ADF first difference } & \multicolumn{2}{l|}{ PP Level } & \multicolumn{2}{l}{ PP first difference } \\
\cline { 2 - 9 } & $t$-stat & Prob. & $t$-stat & Prob. & $t$-stat & Prob. & $t$-stat & Prob. \\
\hline ln real p & -2.992 & 0.1357 & -14.911 & 0.0000 & -2.758 & 0.2142 & -14.856 & 0.0000 \\
\hline ln real poil & -2.431 & 0.3627 & -14.537 & 0.0000 & -2.173 & 0.5029 & -14.026 & 0.0000 \\
\hline In real fed fund & -1.068 & 0.9316 & -11.719 & 0.0000 & -0.940 & 0.9489 & -11.642 & 0.0000 \\
\hline ln rex & -2.355 & 0.4028 & -13.605 & 0.0000 & -2.339 & 0.4111 & -13.544 & 0.0000 \\
\hline ln end stock to use & -3.066 & 0.1162 & -18.986 & 0.0000 & -3.124 & 0.1022 & -18.986 & 0.0000 \\
\hline sst & -4.111 & 0.0066 & & & -3.853 & 0.0150 & -12.365 & 0.0000 \\
\hline soi & -5.796 & 0.0000 & & & -9.232 & 0.0000 & & \\
\hline ln us cpi & -2.674 & 0.2480 & -11.595 & 0.0000 & -3.129 & 0.1010 & -10.555 & 0.0000 \\
\hline ln world ind prod & -1.775 & 0.7150 & -6.058 & 0.0000 & 1.850 & 0.9848 & -44.358 & 0.0000 \\
\hline us fed spread & -4.484 & 0.0018 & & & -3.363 & 0.0580 & -13.339 & 0.0000 \\
\hline ln thinness & -2.636 & 0.2645 & -18.783 & 0.0000 & -2.900 & 0.1637 & -18.782 & 0.0000 \\
\hline ln speculation & -6.668 & 0.0000 & & & -6.766 & 0.0000 & & \\
\hline
\end{tabular}

Note: test equation includes trend and intercept. Mac Kinnon crit-values. The sample consists of monthly observation spanning the period from 1980 to 2012. The sample refers to the period 19952012 only with regard to speculation. Null hypothesis: there is a unit root. Real $\mathrm{p}=$ real wheat price, real poil $=$ real oil price, real fed fund $=$ real federal fund, rex $=$ real effective exchange rate, sst $=$ sea surface temperature anomalies, soi $=$ Southern oscillation index anomalies, $\mathrm{us} \mathrm{cpi}=\mathrm{US}$ inflation rate, world ind prod $=$ world industrial production, US fed spread $=$ US bond yield, thinness $=$ thinness of the market, speculation $=$ excessive speculation

one because the series was confirmed by a supplementary Kwiatkowski, Phillips, Schmidt, and Shin (KPSS) test (1992). The outcomes of the tests are reported in Table 10.1. The presence of non-stationarity implies that standard time-series methods are no longer suitable. And consequently, a cointegration analysis is required (Enders 2009).

To have a broader indication on the variables of interest, the correlation matrix has been computed ${ }^{6}$ (Table 10.2).

relation, although this terminology is not in the spirit of the original definition because it can happen that a linear combination of $\mathrm{I}(0)$ variables is called a cointegration relation." Therefore, even in the presence of a set of variables which contains both $\mathrm{I}(1)$ and $\mathrm{I}(0)$ variables, cointegration analysis is applicable, and the presence of a long-run linear combination denotes the existence of cointegrated variables. Hence, it is possible to find long-run equilibrium relationships among a set of $\mathrm{I}(0)$ and $\mathrm{I}(1)$ variables if their linear combination reveals a cointegrating relationship.

${ }^{6}$ On the basis of the variance inflation factor, the variable ln us cpi was excluded from the model because it is highly correlated with the world industrial production. Further, the inclusion of the inflation rate would have caused a clear problem of endogeneity. 


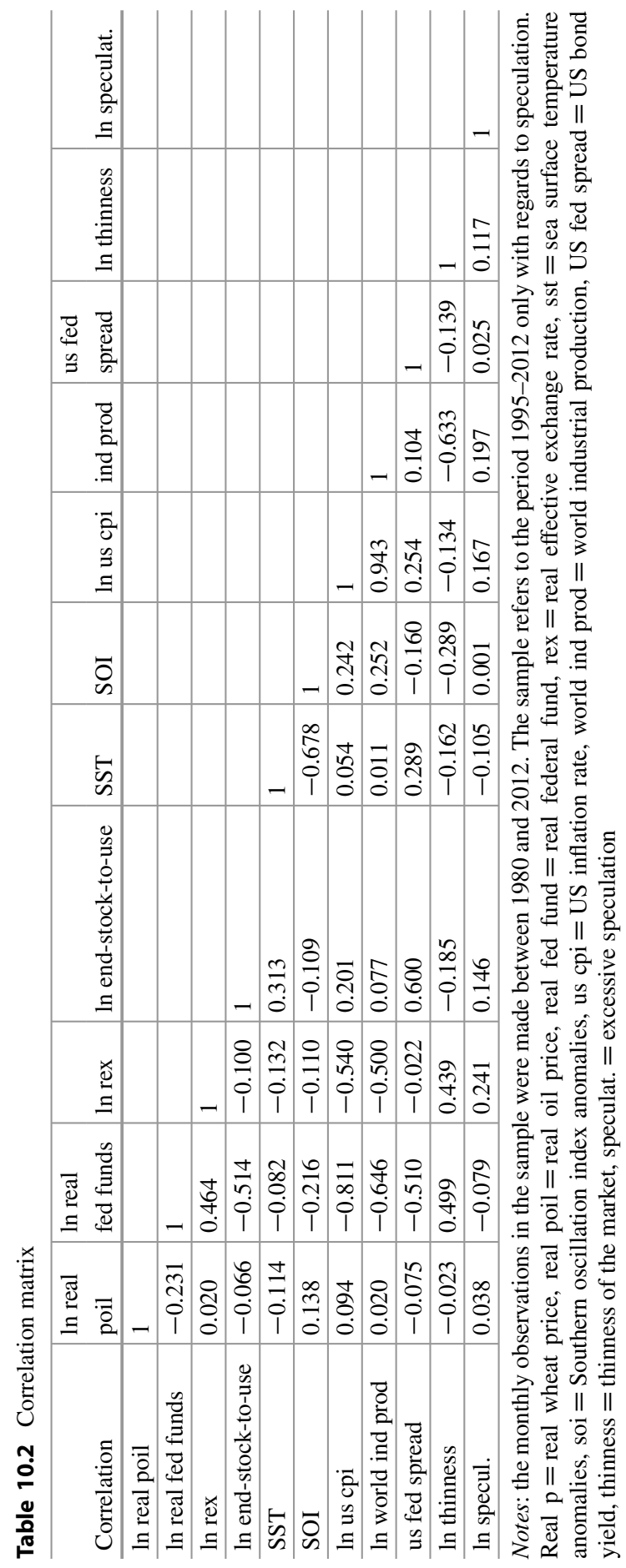




\subsubsection{Johansen and Juselius Analysis}

The Johansen and Juselius methodology (1990), based on maximum-likelihood estimation, allows for the simultaneous evaluation of equations involving two or more variables and for determining whether the series are cointegrated; that is to say, whether there is a long-term relationship among variables. Furthermore, this technique controls for endogeneity and enables us to assess and test for the presence of more than one cointegrating vector. Finally, this methodology performs better than other estimation methods by including additional lags, even when the errors are non-normal distributed or when the dynamics are unknown, and the model is over-parameterized (Gonzalo 1994).

Consider a $p$-dimensional vector autoregressive model, which in error correction form is given by:

$$
\Delta x_{t}=\Pi x_{t-p}+\sum_{i=1}^{p-1} \Gamma_{i} \Delta x_{t-i}+\Phi S_{t}+\xi_{t}
$$

where $\Delta$ is the difference operator, and $x_{t}=(k \times 1)$ is the vector of nonstationary I(1) variables, explicitly:

$$
\begin{aligned}
x_{t}= & {\left[\text { wheat }_{\text {price }} ; \text { market specific variables }_{t} ; \text { broad macro variables }_{t} ;\right.} \\
& \text { weather } \left._{t} ; \text { speculation }_{t}\right]
\end{aligned}
$$

and:

$$
\begin{array}{r}
\Pi=\sum_{i=1}^{p} A_{i}-I \quad I=a(k \times k) \text { identity matrix } \\
\Gamma_{i}=\sum_{j=1}^{i} A_{j}-I \quad A=a(k \times k) \text { matrix of parameters }
\end{array}
$$

The variable $S t$ contains a constant term and a time trend, and $\xi$ is a vector of Gaussian, zero mean disturbances. $\Gamma_{i}$ are $(k \times k)$ dimensional matrices of autoregressive coefficients. The long-run matrix $\prod$ can be decomposed as the product of $\alpha$ and $\beta$, two $(k \times r)$ matrices each of rank $r$, such that $\prod=\alpha \beta$, where $\beta$ ' contains the $r$ cointegrating vectors and $\alpha$ represents the adjustment parameters, which reflect the speed of adjustment of the particular variables with respect to a disturbance in the equilibrium relationship. Therefore, Eq. (10.3) becomes:

$$
\Delta x_{t}=(\alpha \beta) x_{t-p}+\sum_{i=1}^{p-1} \Gamma_{i} \Delta x_{t-i}+\Phi S_{t}+\xi_{t}
$$


The maximum-likelihood approach makes it possible to test the hypothesis of $\mathrm{r}$ cointegrating relations among the elements of $x_{t}$,

$$
H_{0}: \Pi=\alpha \beta
$$

where the null of no cointegration relation $(r=0)$ implies $\prod=0$. If $\prod$ is of rank $k$, the vector process is stationary. If $\operatorname{rank}\left(\prod\right)=1$, there is a cointegrating vector; for other cases in which $1<\operatorname{rank}\left(\prod\right)<k$, there are multiple cointegrating vectors.

\subsubsection{Empirical Results}

A VAR system of variables was constructed to test whether real wheat prices are cointegrated with specific market variables, broad macroeconomic factors, speculation, and weather events. To identify the proper model, the five possibilities considered by Johansen (1995) were tested, specifically: (1) the series have no deterministic trends, and the cointegrating equations do not have intercepts; (2) the series have no deterministic trends, and the cointegrating equations have intercepts; (3) the series have linear trends, but the cointegrating equations only have intercepts;

(4) both series and the cointegrating equations have linear trends; and (5) the series have quadratic trends, and the cointegrating equations have linear trends. Following the Pantula test (Pantula 1989), the third and the fifth models are the most appropriate for two samples. To identify the lag length, the Aikaike information criterion (AIC) and the SIC were implemented. The chosen lag structure is three (the smallest value) for the complete sample and five for the subsample, following the AIC. A number of dummies have been included in the cointegration test to take into account periods of social and economic instability and structural breaks. ${ }^{7}$

The results of the Johansen test for cointegration are shown in Table 10.3, which reports the hypothesized number of cointegration equations in the first column on the left, the eigenvalue, the $\operatorname{trace}^{8}$ statistics, the max eigenvalue statistics, ${ }^{9}$ and the $5 \%$ critical values. The asterisks indicate the rejection of the hypothesis.

\footnotetext{
${ }^{7}$ Specifically, outliers were detected by looking at the graphs of the residuals. Five dummies relative to $1998,2007,2008,2010$, and 2011 were inserted in the short-sample wheat price equation. The effects of including dummy variables to capture structural breaks in cointegration models have been analyzed in Kremers et al. (1992), and Campos et al. (1996).

${ }^{8}$ The trace statistic of $\mathrm{r}$ cointegration relations is a sequence of likelihood ratio tests, computed as $\lambda_{\text {trace }}(r)=-T \sum_{i=r+1}^{k} \ln \left(1-\widehat{\lambda}_{i}\right)$, where $\lambda_{i}$ is the estimated value of the characteristic roots (also called eigenvalue) obtained from the estimated long-run $\Pi$ matrix, and $T$ is the number of usable observations.

${ }^{9}$ The max eigenvalue statistic is calculated as $\lambda_{t \max }(r)=-T \ln \left(1-\widehat{\lambda}_{r+1}\right)$.
} 
Table 10.3 Johansen cointegration tests

Sample (adjusted). Included observations: 365 after adjustments Trend assumption:

Quadratic deterministic trend

Unrestricted cointegration rank test (trace)

\begin{tabular}{l|l|l|l|l}
\hline Hypothesized no. of CE(s) & Eigenvalue & Trace statistic & $5 \%$ Critical value & Prob. $^{* *}$ \\
\hline None* & 0.172 & 233.630 & 219.402 & 0.0090 \\
\hline At most 1 & 0.111 & 164.650 & 179.510 & 0.2206 \\
\hline At most 2 & 0.097 & 121.810 & 143.669 & 0.4306 \\
\hline At most 3 & 0.077 & 84.592 & 111.780 & 0.6913 \\
\hline At most 4 & 0.050 & 55.509 & 83.937 & 0.8503 \\
\hline
\end{tabular}

Trace test indicates 1 cointegrating eqn(s) at the 0.05 level

Unrestricted cointegration rank test (maximum eigenvalue)

\begin{tabular}{l|l|l|l|l}
\hline Hypothesized no. of CE(s) & Eigenvalue & Max-Eigen statistic & 5 \% Critical value & Prob. $^{* *}$ \\
\hline None* & 0.172 & 68.980 & 61.034 & 0.0071 \\
\hline At most 1 & 0.111 & 42.839 & 54.966 & 0.4688 \\
\hline At most 2 & 0.097 & 37.219 & 48.877 & 0.4742 \\
\hline At most 3 & 0.077 & 29.083 & 42.772 & 0.6531 \\
\hline At most 4 & 0.049 & 18.565 & 36.630 & 0.9422
\end{tabular}

Max-eigenvalue test indicates 1 cointegrating eqn(s) at the 0.05 level

Sample (adjusted). Included observations: 173 after adjustments. Trend assumption: Linear deterministic trend

\begin{tabular}{|c|c|c|c|c|}
\hline \multicolumn{5}{|c|}{ Unrestricted cointegration rank test (trace) } \\
\hline Hypothesized no. of CE(s) & Eigenvalue & Trace statistic & $5 \%$ Critical value & Prob. $^{* * * *}$ \\
\hline None $^{*}$ & 0.362 & 350.632 & 285.142 & 0.0000 \\
\hline At most $1^{*}$ & 0.304 & 272.774 & 239.235 & 0.0006 \\
\hline At most $2^{*}$ & 0.296 & 210.063 & 197.371 & 0.0100 \\
\hline At most 3 & 0.248 & 149.364 & 159.530 & 0.1561 \\
\hline At most 4 & 0.167 & 100.126 & 125.615 & 0.5978 \\
\hline
\end{tabular}

Trace test indicates three cointegrating eqn(s) at the 0.05 level

Unrestricted cointegration rank test (maximum eigenvalue)

\begin{tabular}{l|l|l|l|l}
\hline Hypothesized no. of CE(s) & Eigenvalue & Max-Eigen statistic & 5 \% Critical value & Prob. $^{* * *}$ \\
\hline None $^{*}$ & 0.362 & 77.858 & 70.535 & 0.0091 \\
\hline At most 1 & 0.304 & 62.711 & 64.505 & 0.0736 \\
\hline At most 2 & 0.296 & 60.699 & 58.433 & 0.0294 \\
\hline At most 3 & 0.248 & 49.239 & 52.363 & 0.1010 \\
\hline At most 4 & 0.167 & 31.672 & 46.231 & 0.6786
\end{tabular}

Max-eigenvalue test indicates 1 cointegrating eqn(s) at the 0.05 level

*Denotes rejection of the hypothesis at the 0.05 level

*** MacKinnon et al. (1999) $p$-values

**** MacKinnon et al. (1999) $p$-values. Estimations include significant dummies 
Elaborating on the trace statistic, the first row of the trace statistic tests the hypothesis of no cointegration, the second row tests the hypothesis of one cointegrating relation, the third row tests the hypothesis of two cointegrating relations, and so on. All hypotheses were tested against the alternative hypothesis of full rank (i.e., all series in the model are stationary). For the longer sample, the $\lambda_{\text {trace }}$ test and the $\lambda_{\max }$ statistic indicate the presence of one cointegrating equation at the $5 \%$ level. For the shorter sample, the $\lambda_{\text {trace }}$ test indicates the presence of three cointegrating equations at the $5 \%$ level. The $\lambda_{\max }$ statistic does not confirm this result. The null hypotheses of no cointegrating vector $(r=0)$ can be rejected at the $5 \%$ level, but the null of $r=1$ cannot be rejected. So, it can be concluded that there is one cointegrating vector in the system at the $5 \%$ level.

Although the results of trace tests and maximum eigenvalue tests point to different outcomes, we can conclude for one cointegrating vector since as Johansen and Juselius note, "one would, however, expect the power of this procedure [the trace test] to be low, since it does not use the information that the last three eigenvalues have been found not to differ significantly from zero. Thus, one would expect the maximum eigenvalue test to produce more clear-cut results" (1990, p. 19).

To extract the cointegrating vectors, a VEC representation has been adopted. Convergence was reached after few iterations for the entire sample and the small sample. The restricted cointegrating vectors and the speed of adjustment coefficients are reported in Table 10.4 .

Table 10.4 Vector error correction estimations

\begin{tabular}{l|c|c}
\hline Cointegrating vector $\beta$ & $1981: 1-2012: 1$ & $1995: 1-2012: 1$ \\
\hline $\ln$ real poil & $0.231(4.44)$ & $0.294(2.84)$ \\
\hline $\ln$ real fed funds & $-0.132(-2.55)$ & $-0.207(-6.03)$ \\
\hline $\ln$ rex & $-0.771(-3.12)$ & $-0.726(-9.77)$ \\
\hline ln end-stock-to-use & $-0.999(-3.94)$ & $-0.436(-1.99)$ \\
\hline sst & $-0.244(-3.50)$ & $-0.248(-4.54)$ \\
\hline soi & $0.166(5.71)$ & $0.104(4.26)$ \\
\hline ln world ind prod & $3.290(2.80)$ & $1.807(2.63)$ \\
\hline us fed spread & $0.045(1.99)$ & $0.021(1.09)$ \\
\hline ln thinness & $-1.008(-2.56)$ & $0.340(1.42)$ \\
\hline ln speculation & & $0.715(7.14)$ \\
\hline Constant & 27.990 & 25.800 \\
\hline Trend & $0.006(3.51)$ & $0.001(2.01)$ \\
\hline Speed of adjustment $\alpha$ & & \\
\hline dln real price index & $-0.069(-4.87)$ & $-0.085(-2.07)$ \\
\hline Regress
\end{tabular}

Regressand: In real wheat price index. $t$-stat in brackets. In stands for logarithm 


\subsubsection{Discussion of Results and implications}

The cointegration analysis suggests that real wheat prices were cointegrated with market specific variables, broad economic variables, weather events, and speculation. In particular, the columns of $\beta$ in Table 10.4 are interpreted as long-run equilibrium relationships between variables, and the matrix $\alpha$ is used to determine the speed of adjustment towards this equilibrium. The estimated speeds of adjustment coefficients had the expected signs and were statistically significantly different from zero. This means that the cointegrating vectors converged towards their longrun equilibrium in the presence of a shock to the system. Expressly, $6.9 \%$ of the disequilibrium was eliminated in 1 month for the complete sample, and this figure was $8.5 \%$ for the subsample; that is, it took 14.5 months (1/0.069) and 11.7 months (1/0.085), respectively, to restore the equilibrium after a shock.

More specifically, Table 10.4 provides evidence to suggest that higher oil prices have led to an increase in wheat prices due to greater use of petroleum-based inputs in the wheat market. In other words, on the supply side, a rise in oil prices exerts an upward pressure on the input costs (such as fertilizers, irrigation, and transportation costs), which consequently leads to a decline in profitability and production. This results in a shift of the supply curve to the left and a rise in wheat prices. The result provides evidence that energy and agricultural prices are interwoven. A $10 \%$ increase in international oil prices is statistically associated with an approximately $2.3 \%$ rise in wheat prices for the longer sample and a $2.9 \%$ increase for the shorter sample, all other things being equal. This result is in line with the studies by Tang and Xiong (2012) and Chen et al. (2010), who found an increasing correlation between agricultural commodities and oil price.

In addition, wheat prices appear to be sensitive to fluctuations in the real exchange rate. The sensitivity to fluctuation is almost the same for the two samples, both before and after the financialization of the wheat market. Specifically, the elasticity of about -0.7 suggests that a real dollar depreciation causes wheat prices to rise as wheat prices are denominated in the US dollar. The coefficients of the real exchange rate fell in a range between 0 and -1 , just as predicted by the economic theory (Gilbert 1989; Borensztein and Reinhart 1994).

The real federal fund variable is negatively linked to the real wheat price, thus confirming the presence of the monetary policy effect. A loose monetary stance (with a lower interest rate of $1 \%$ ) implies that the price level will increase by about 0.1 and $0.2 \%$. When the real interest rate is high, as in the 1980s, money will flow out of commodities and therefore prices shrink. This confirms the studies by Dornbusch (1976), Frankel (2008), Svensson (2008), and Anzuini et al. (2012). The studies highlighted the high responsiveness of agricultural prices to monetary policy changes. The spread variable has a positive sign, signaling that the future expectations of tightened monetary policies do not have a depressing effect on 
wheat prices and that the Treasury bond market and the wheat commodity market are treated as substitutes asset classes for portfolio diversification. In other words, when the long-term interest rate is higher than the short-term interest rate, it signals an increase in the financial and macroeconomic risk linked to Treasury bonds. This causes investors to shift from the bond market to the commodity market, which in turn raises commodity prices. A $10 \%$ increase in the spread increased prices by about $0.5 \%$; this value decreased to $0.2 \%$ in the short sample and became insignificant.

The stocks-to-use ratio is used to capture the effects of market supply and demand factors on price determination (Westcott and Hoffman 1999). The variable shows a negative relationship with the wheat price. When usage grows faster than ending stocks, it would imply that demand growth outpaces supply growth, which puts an upward pressure on prices. Specifically, a reduction in the stocks-to-use ratio by $1 \%$ caused real prices to surge by $0.9 \%$ for the longer sample and $0.4 \%$ for the shorter sample. This means that the combined effects of market supply and demand are factors in determining prices. It also means that a rise in the stocks-to-use ratio of a commodity translates into an almost proportional drop in the commodity's price in the longer sample, while the effect is less pronounced in the shorter sample.

As expected, bad weather conditions negatively affected wheat prices. Specifically, La Niña weather patterns tended to lower wheat yields and lift prices. It should be noted that the sea surface temperature anomalies had a larger impact than the fluctuations in air pressure occurring between the western and eastern tropical Pacific during El Niño and La Niña episodes. However, since the variability of SOI is larger than SST, the SOI could have more detrimental effects for wheat production and prices.

A $1 \%$ increase in industrial production produced a significant rise in wheat prices by about $2-3 \%$. This implies, in accordance with the studies by Svensson (2008) and Wolf (2008), that the global demand is an important determinant of commodity prices.

The thinness of the market, while negative and significant for the longer sample, turned out to be not significant for the shorter sample. This implies that trade restriction policies could exert a detrimental effect as they tend to push wheat prices further up.

Finally, the speculation variable that is included only in the shorter sample indicates that the financialization of markets has contributed to pushing up prices. In traded markets, when futures traders seek exposure to commodities without holding the underlying commodities and speculate on future price movements of the commodity, they amplify price fluctuations on cash markets. This implies that speculative behaviors in the wheat futures market affect the associated spot market. According to our model, a $1 \%$ increase in financial speculation increased cash prices by about $0.7 \%$. 
In summary, the estimated coefficients showed that market specific variables, broad macroeconomic variables, speculative components, and weather conditions have a significant effect on real wheat prices, and thus the existing theories complement rather than contradict one another. The key to understanding the findings of this study is that commodities have multiple uses: they are both consumption goods and financial assets for investments. The positive effect of world demand on wheat commodity prices showed that wheat is used as consumption goods. The positive impact of open interest and yield curve on wheat price demonstrated that wheat is also used as financial assets.

An increasing demand was a dominant factor in driving up wheat prices, together with inventories for the longer sample; excessive speculation turned out to be significant and a relevant factor behind the price swings for the shorter sample. Pressures on real prices were alleviated by restrictive monetary policies, a real dollar appreciation, and, to some extent, expansive trade policies.

The properties of the residuals of the estimated model have been carefully analyzed. A battery of tests revealed that the residuals were stationary, homoskedastic, and uncorrelated. The estimated model was also "dynamically stable". ${ }^{10}$

\subsection{Conclusions}

The roller-coaster ride which commodity prices have experienced over the last decade has generated considerable interest among academics, policy makers, and investors in its effects on the real economy and thus on economic growth, food security, and investment decisions. In this context, the present study has tried to shed light on the key factors affecting the price movements of wheat, one of the major food grains in the world. The analysis was carried out for the period 1980-2012 and the subperiod 1995-2012, using monthly data.

The results of the study indicated that all the theories about drivers of commodity price do not necessarily contradict, but rather complement, each other. In fact, the results showed that a complex amalgamation of factors have caused prices to rapidly increase in the wheat markets, including speculation in futures markets, macroeconomic fundamentals, market specific variables, and weather conditions.

Wheat prices have been pushed up by a myriad of factors: loose monetary policies (as evident in low real interest rates), higher levels of industrial production (a proxy for strong economic activities), and speculative pressure. An increase in the stock-to-use ratio and a real appreciation has a curbing or dampening effect on

\footnotetext{
${ }^{10}$ The residual analysis, including details about stability, and the short-run dynamics are not reported for brevity but are available upon request. The impulse response function representation based on the Cholesky decomposition method indicates that short-run wheat price patterns in response to a shock are rich, and the impact of the shock is long-lasting. The variance decomposition based on Monte Carlo repetitions confirmed that there is a long-run relationship between the variables, and that all the determinants are meaningful in predicting real wheat prices when considered as a whole.
} 
wheat prices. The thinness of a market turns out to be insignificant in the short sample, but it plays a role in the long sample, exerting an upward pressure on prices when trade diminishes.

Furthermore, the study has shown that an additional factor behind the rise in wheat prices is the increase in oil prices. Higher oil prices makes wheat production more expensive by raising the cost of inputs like fertilizers, irrigation, and transportation, thereby decreasing the profitability and production of wheat and raising wheat prices.

The variables with the largest effects on price movements over the period 19952012 are the global demand, speculation, and the real effective exchange rates. This showed that financial and wheat markets are becoming increasingly interwoven. It also showed that "speculation" which involves trading futures contracts on commodity markets (to profit from price fluctuations) is an important determinant of price dynamics. The wider and more unpredictable price changes are caused by greater possibilities of realizing large gains by speculating on future price movements of the commodity in question. Although the presence of "speculators" on derivatives markets is a necessary condition for a well-functioning market and efficient hedging, price fluctuations can also attract significant speculative activities and destabilize markets, which are both the cause and the effect of increased prices.

The adopted model satisfied the stability conditions as well as other residuals properties, and it indicated that cointegrating vectors will converge towards their long-run equilibrium in the presence of a shock to the system after 14.7 months and 11.7 months for the two sample periods, respectively.

Acknowledgments This chapter is based on the article "A roller coaster ride: an empirical investigation of the main drivers of the international wheat price" published by the same author in Agricultural Economics Volume 45, Issue 4, pages 459-475, July 2014. Reproduced with permission of John Wiley \& Sons, Inc. The author is grateful to Prof. Gerald Shively, Editorin-Chief of Agricultural Economics, and two anonymous referees for their valuable comments and suggestions. The author would like to thank Prof. Joachim von Braun, Dr. Matthias Kalkuhl, Prof. Antonio Aquino, and the participants at the international Workshop on "Food price volatility and food security," held in Bonn, Germany, Center for Development Research (ZEF, Bonn University), 31 January-1 February, 2013, for their helpful comments. Financial support from the Federal Ministry for Economic Cooperation and Development, BMZ (Scientific Research Program on "Volatility in food commodity markets and the poor"), is gratefully acknowledged. 


\section{Annex}

\begin{tabular}{|c|c|}
\hline $\begin{array}{l}\text { Market price for } \\
\text { wheat }\end{array}$ & $\begin{array}{l}\text { This is a market price series for wheat, with values } \\
\text { expressed in US dollars and averaged from daily } \\
\text { quotations. The commodity and market specifications are: } \\
\text { US No. } 1 \text { hard red winter, ordinary protein, prompt } \\
\text { shipment, FOB Gulf of Mexico ports. The series was } \\
\text { collected from Datastream }\end{array}$ \\
\hline $\begin{array}{l}\text { Real effective } \\
\text { exchange rate }\end{array}$ & $\begin{array}{l}\text { The US real effective exchange rate series take into account } \\
\text { not only changes in market exchange rates but also } \\
\text { variations in relative price levels (using consumer prices). } \\
\text { The data was taken from Datastream USOCC011 }\end{array}$ \\
\hline Oil spot prices & $\begin{array}{l}\text { This variable has been collected from EIA database and } \\
\text { refers to Cushing, Oklahoma WTI (West Texas } \\
\text { Intermediate) Spot Price FOB (Dollars per Barrel), } \\
\text { Datastream USWTIOIL }\end{array}$ \\
\hline Stock-to-use & $\begin{array}{l}\text { Data was taken from the USDA http://usda.mannlib.cornell. } \\
\text { edu/MannUsda/viewDocumentInfo.do?documentID=1194 }\end{array}$ \\
\hline $\begin{array}{l}\text { El Niño region } 3.4 \\
\text { sea surface } \\
\text { temperature } \\
\text { anomalies (SST) }\end{array}$ & $\begin{array}{l}\text { Data was taken from the National Climatic Data Center US } \\
\text { Department of Commerce and NOAA Satellite and } \\
\text { Information Service using the extended reconstructed sea } \\
\text { surface temperature; http://www.ncdc.noaa.gov/ersst/ftp:// } \\
\text { ftp.ncdc.noaa.gov/pub/data/cmb/ersst/v3b/pdo ftp://ftp. } \\
\text { ncdc.noaa.gov/pub/data/cmb/ersst/v3b/pdo/el_nino.dat }\end{array}$ \\
\hline $\begin{array}{l}\text { The southern } \\
\text { oscillation index } \\
\text { (SOI) }\end{array}$ & $\begin{array}{l}\text { Data was taken from National Oceanic and Atmospheric } \\
\text { Administration National Climatic Data Center;http://www. } \\
\text { ncdc.noaa.gov/teleconnections/enso/indicators/soi. } \\
\text { php http://www.cpc.ncep.noaa.gov/data/indices/soi }\end{array}$ \\
\hline Real federal funds & $\begin{array}{l}\text { The US money market rate (federal funds) deflated by the } \\
\text { consumer price. The Series refers to the weighted average } \\
\text { rate at which banks borrow funds through New York } \\
\text { brokers. Monthly rate is the average of rates of all calendar } \\
\text { days. Data was collected from Datastream }\end{array}$ \\
\hline $\begin{array}{l}\text { US interest rate } \\
\text { spread }\end{array}$ & $\begin{array}{l}\text { It has been constructed as difference between the } 10 \text { year } \\
\text { treasury bonds and the federal fund }\end{array}$ \\
\hline Global activity & $\begin{array}{l}\text { It is measured as industrial production index taken from } \\
\text { IMF, IFS, via Datastream }\end{array}$ \\
\hline Thinness & $\begin{array}{l}\text { It was computed using data provided by the USDA http:// } \\
\text { usda.mannlib.cornell.edu/MannUsda/viewDocumentInfo. } \\
\text { do?documentID }=1194\end{array}$ \\
\hline
\end{tabular}


Open Access This chapter is distributed under the terms of the Creative Commons AttributionNoncommercial 2.5 License (http://creativecommons.org/licenses/by-nc/2.5/) which permits any noncommercial use, distribution, and reproduction in any medium, provided the original author(s) and source are credited.

The images or other third party material in this chapter are included in the work's Creative Commons license, unless indicated otherwise in the credit line; if such material is not included in the work's Creative Commons license and the respective action is not permitted by statutory regulation, users will need to obtain permission from the license holder to duplicate, adapt or reproduce the material.

\section{References}

Acworth W (2005) Going long on commodities, future industry, 24-28 May/June 2005

Anzuini A, Lombardi MJ, Pagano P (2012) The impact of monetary policy shocks on commodity prices, Bank of Italy, Temi di Discussione, Working paper, 851

Asteriou D, Hall SG (2007) Applied econometrics. A modern approach using eviews and microfit. Palgrave Macmillan, New York

Bakucs ZL, Fałkowski J, Fertô I (2009) Monetary policy and overshooting of flexible sectors in transition economies: the case of Poland. In: Zawojska A (ed) Agri-food System and its Linkages with Global, International and Domestic Economies. Warsaw University of Life Sciences Press, Warsaw, pp 84-95

Benson T, Minot N, Pender J, Robles M, von Braun J (2013) Information to guide policy responses to higher global food prices: the data and analyses required. Food Policy 38(1):47-58

Borensztein E, Reinhart CM (1994) The macroeconomic determinants of commodity prices. IMF Staff Pap 41(2):236-261

Brunner AD (2002) El Niño and world primary commodity prices: warm water or hot air? Rev Econo Stat 84(1):176-183

Büyükşahin B, Harris JH (2011) Do speculators drive crude oil futures prices? Energy J 32(2):167202

Calvo G (2008) Exploding commodity prices, lax monetary policy and sovereign wealth fund, VoxEU, 20 June 2008

Campos J, Ericsson N, Hendry D (1996) Cointegration tests in the presence of structural breaks. J Econ 70(1): 187-220

Cevik S, Sedik TS (2011) A barrel of oil or a bottle of wine: how do global growth dynamics affect commodity prices? IMF working paper, 11(1)

Chen ST, Kuo HI, Chen CC (2010) Modeling the relationship between the oil price and global food prices. Appl Energy 87(8):2517-2525

Coxhead I, Jayasuriya S (2010) China, India and the commodity boom: economic and environmental implications for low-income countries. World Econ 33(4):525-551

De Long B, Shleifer A, Summers L, Waldmann R (1990) Positive feedback investment strategies and destabilizing rational speculation. J Financ 45(2):374-397

Dethier JJ, Effenberger A (2012) Agriculture and development: a brief review of the literature. Econ Syst 36(2): 175-205

Dickey DA, Fuller WA (1981) Likelihood ratio statistics for autoregressive time series with a unit root. Econometrica 49(4):1057-1072

Domanski D, Heath A (2007) Financial investors and commodity markets. BIS Q Rev, Mar 2007

Dornbusch R (1976) Expectations and exchange rate dynamics. J Polit Econ 84(6):1161-1176

Dwyer A, Gardner G, Williams T (2011) Global commodity markets - price volatility and financialisation. Reserve Bank of Australia Bulletin, June Quarter

Dwyer A, Holloway J, Wright M (2012) Commodity market financialisation: a closer look at the evidence. Reserve Bank of Australia Bulletin, March Quarter

Enders W (2009) Applied econometric time series. Wiley, New York 
Engle RF, Granger CWJ (1987) Cointegration and error correction: representation, estimation and testing. Econometrica 55(2):251-276

EPA (2012) Renewable fuel standard. US Environmental Protection Agency. Available at http:// www.epa.gov/otaq/fuels/renewablefuels/index.htm

Erten B, Ocampo JA (2013) Super-cycles of commodity prices since the mid-nineteenth century. World Dev 44:14-30

FAO (2009) The state of agricultural commodity markets: high food prices and the food crisisexperiences and lessons learned. Available at ftp://ftp.fao.org/docrep/fao/012/i0854e/i0854e.pdf

Fawley BW, Juvenal L (2011) Commodity price gains: speculation vs. fundamentals. Reg Econ, July 2011

Frankel JA (2006) The effect of monetary policy on real commodity prices, NBER working paper, 12713

Frankel JA (2008) The effect of monetary policy on real commodity prices. In: Campbell J (ed) Asset prices and monetary policy. University of Chicago Press, Chicago, pp 291-327

Frankel JA (2012) Commodity prices and interest rates. CoBank Outlook Econ Data Comment 9(10):1-6

Frankel JA (2013) Effects of speculation and interest rates in a "Carry Trade" model of commodity prices. Harvard Kennedy School, Harvard University, Faculty Research Working Paper Series RWP13-022, 18 June 2013

Frankel JA, Rose AK (2009) Determinants of agricultural and mineral commodity prices. Reserve bank of Australia annual conference volume 2009-02

Friedmann M (1953) The case for flexible exchange rate. In: Friedmann M (ed) Essays in positive economics. University of Chicago Press, Chicago, pp 157-203

Gilbert CL (1989) The impact of exchange rate changes and developing country debt on commodity prices. Econ J 99(397):773-784

Gilbert CL, Morgan WC (2011) Food price volatility. In: Di Isabelle Piot-Lepetit, M'barek R (eds) Methods to analyse agricultural commodity price volatility, Chap 4. Springer, Berlin, pp 45-61

Gonzalo J (1994) Five alternative methods of estimating long-run equilibrium relationships. J Econ 60(1):203-233

Goodwin BK, Schroeder TC (1991) Dynamics in international wheat markets. Can J Agric Econ 39(2):237-254

Hamilton J (2009) Understanding crude oil prices. Energy J 30(2):179-206

Heap A (2005) China. The engine of a commodities super-cycle, Working paper, Smith Barney; Citigroup New York City

Hurtado R, Berri GJ (1998) Relationship between wheat yields in the humid Pampa of Argentina and ENSO during the period 1970-1997, 10th Brazilian Congress of Meteorology, Brasilia, Brazil

IMF (2006) Global financial stability report, Sept 2006, Washington, DC

IMF (2011) Commodity price swings batter most vulnerable in poorest countries. IMF survey magazine: countries \& regions, 23 Sept 2011

Irwin SH, Sanders DR (2010) The impact of index and swap funds on commodity futures markets: preliminary results, OECD food, agriculture and fisheries working papers, no. 27, OECD Publishing

Irwin SH, Sanders DR, Merrin RP (2009) Smart money? The forecasting ability of CFTC large traders in agricultural futures markets. J Agric Resour Econ 34(2):276-296

Jacks DS (2013) From boom to bust: a typology of real commodity prices in the long run, NBER working paper, 18874

Jacks DS, O'Rourke KH, Williamson JG (2011) Commodity Price Volatility and World Market Integration since 1700. Rev Econ Stat 93(3):800-813

Johansen S (1995) Likelihood based inference in cointegrated vector autoregressive models. Oxford University Press, Oxford

Johansen S, Juselius K (1990) Maximum likelihood estimation and inference on cointegration with applications to the demand of money. Oxf Bull Econ Stat 52(2):169-210 
Kremers J, Ericsson N, Dolado J (1992) The power of cointegration tests. Oxf Bull Econ Stat 54(3):349-367

Krugman P (2010a) Nobody believes in supply and demand. NY Times, 28 Dec 2010

Krugman P (2010b) The finite world. NY Times, 26 Dec 2010

Krugman P (2011) Commodities: this time is different. NY Times, 29 Jan 2011

Kwiatkowski D, Phillips PCB, Schmidt P, Shin Y (1992) Testing the null hypothesis of trend stationarity. J Econ 54(1-3):159-178

Lütkepohl H, Krätzig M (2004) Applied time series econometrics. Cambridge University Press, Cambridge

MacKinnon JG (1991) Critical values for cointegration tests. In: Engle RF, Granger CWJ (eds) Long-run economic relationships: readings in cointegration. Oxford University Press, Oxford, pp 267-276

MacKinnon JG, Haug AA, Michelis L (1999) Numerical distribution functions of likelihood ratio tests for cointegration. J Appl Econ 14(5):563-577

Manera M, Nicolini M, Vignato I (2013) Financial speculation in energy and agriculture futures markets: a multivariate GARCH approach. Energy J 34(3):55-81

Masters MW (2008) Testimony before the Committee on Homeland Security and Government Affairs, U.S. Senate, 20 May 2008

Mercer-Blackman V, Samiei H, Cheng K (2007) Biofuel demand pushes up food prices. IMF Surv Mag: IMF Res. Available at http://www.imf.org/external/pubs/ft/survey/so/2007/RES1017A. htm

Micu M (2005) Declining risk premia in the crude oil futures markets. BIS Q Rev, Dec 2005

Miffre J (2011) Long-short commodity investing: implications for portfolio risk and market regulations. EDHEC-Risk Institute Publication, August, France

Miffre J, Brooks C (2013) Did long-short investors destabilize commodity markets? University of Reading, ICMA Centre, Discussion paper 03, UK

Mitchell D (2008) A note on rising food prices. The World Bank. Development Prospects Group, July 2008

Mussa M (1986) Nominal exchange rate regimes and the behavioural of real exchange rates: evidence and implications. Carn-Roch Conf Ser Public Policy 25:117-214

OECD (2008) Rising food prices: causes and consequences. OECD, Paris

Orden D, Fackler P (1989) Identifying monetary impacts on agricultural prices in VAR models. Am J Agric Econ 71(2):495-502

Pantula SG (1989) Testing for unit roots in time series data. Econ Theory 5(2):256-271

Phillips RCB, Perron P (1988) Testing for a unit root in time series regression. Biometrika 75(2):335-346

Pindyck RS (2001) The dynamics of commodity spot and futures markets: a primer. Energy J 22(3): $1-29$

Portillo R, Zanna F (2011) Inflation in Sub-Saharan Africa during the 2008 commodity price surge, World Economic outlook, IMF, Chap 3. In: Target what you can hit: commodity price swings and monetary policy, IMF, Washington, DC

Roache S (2010) What explains the rise in food price volatility? IMF working paper, no. 10/129

Roberts MJ, Schlenker W (2010) Identifying supply and demand elasticities of agricultural commodities: implications for the us ethanol mandate, NBER working paper, no. 15921

Robles M, Torero M, von Braun J (2009) When speculation matters, Issue Brief 57. International Food Policy Research Institute, Washington, DC. Available at http://www.ifpri.org/sites/default/ files/publications/ib57.pdf

Rogers J (2004) Hot commodities: how anyone can invest and profit in the world's best market. Random House, New York

Russell JS, Mcleod I, Dale MB (2010) Combined Southern oscillation index and sea surface temperatures as predictors of seasonal rainfall, CSIRO Division of Tropical Crops and Pastures, Brisbane, Australia. Available at http://icoads.noaa.gov/Boulder/Boulder.Russell.pdf

Sanders DR, Irwin SH, Merrin RP (2010) The adequacy of speculation in agricultural futures markets: too much of a good thing? Appl Econ Perspect Policy 32(1):77-94 
Stewart H (2008) Speculators fuel bubble in global food costs. Observer, 20 Apr 2008

Svensson LEO (2008) The effect of monetary policy on real commodity prices: comment. In: Campbell JY (ed) Asset prices and monetary policy. NBER, University of Chicago, Chicago, and NBER Working paper, no. 12713

Tang K, Xiong W (2012) Index investment and financialization of commodities. Financ Anal J 68(6):54-74

The Economist (2011). May, 26th Food in Africa. A recipe for riots

The World Bank (2012) Global monitoring report 2012 food prices, nutrition, and the millennium development goals. The World Bank, Washington, DC

Thompson W, Meyer S, Westhoff P (2009) How does petroleum price and corn yield volatility affect ethanol markets with and without an ethanol use mandate? Energy Policy 37(2):745-749

Timmer CP (2009) Rice price formation in the short run and the long run: the role of market structure in explaining volatility, Center for Global Development, working paper number 172, Center for Global Development, Washington, DC

Trostle R (2008) Global agricultural supply and demand: factors contributing to the recent increase in food commodity prices. Washington, DC. Available at http://www.ers.usda.gov/Publications/ WRS0801/

USS/PSI, United States Senate, Permanent Subcommittee on Investigations (2009) Excessive speculation in the wheat market, Washington, DC, 24 June 2009

von Braun J, Tadesse G (2012) Global food price volatility and spikes: an overview of costs, causes, and solutions, ZEF Discussion Papers on Development Policy, 161, University of Bonn, Germany

Westcott PC, Hoffman LA (1999) Price determination for corn and wheat: the role of market factors and government programs, U.S. Department of Agriculture/Economic Research Service, Market and Trade Economics Division, Technical Bulletin No. 1878, Washington, DC

Williams JC, Wright B (1991) Storage and commodity markets. Cambridge University Press, Cambridge, UK

Wolf M (2008) Life in a tough world of high commodity prices. Financ Times, 4 Marc 2008

Working H (1953) Futures trading and hedging. Am Econ Rev 43(3):314-343

Yellen JL (2011) Commodity prices, the economic outlook and monetary policy. Economic Club of New York, New York, NY, 11 Feb 2011. Available at http://www.federalreserve.gov/ newsevents/speech/yellen20110411a.pdf 